\title{
The Possible Applications of Bauhaus Educational Concept for Teaching Architecture Today
}

\author{
By : Wiryono Rahardjo'
}

Wiryono Rahardjo, lahir di Yogyakarta, 26 September 1962 adalah alumnus Fakultas Teknik Arsitekiur Universitas Gadjah Mada tahun 1987, tahun 1981 - 82 mengikutiprogram pertukaran Mahassiswa The Taieri High School, Mosgiel, Otago, New Zealand. Tahun 1983 - 1985:Sebagai tenaga perencana pada berbagai proyek pembangunan di'Prop.D.I.Y. sekarang sebagai staff pengajar dan Ketua Jurusan Fakultas Teknik Arsitektur UII, dan sedang mengambil program Master of Architecture, pada Techical University of Nova Scotia, Halifax, Nova Scotia, Canada.

\section{Introduction}

In early 20 th century, Europe was shocked by a new movement of art and architecture as a result 'of Bauhaus educations. It was Walter Gropius - a world class German architect - who generated the idea of rationalization and standardization of building, and transfonmed his concept through his Bauhaus school in Weimar, Dessau, Berlin, and Chicago. The aim of this school was to educate students from various fields of interest such as painting, dancing, and sculpting, to become qualified architects. Bauhaus actually existed for only fourteen years (1919-1933) and had to move from city to city. However, this institution played an important role in influencing the attitude of design and people's view toward art and architecture in those days, even today, because of itsinno- vative educational approach.

This paper examines the Bauhaus curricula during its existence from 1919 to 1933 and suggests the possible applications for teaching and learning by utilizing Diamond's program development model. The curricula are viewed at its static value (as a concept). A typical sequence of instruction is developed as a result of curriculum evalution. Based on Diamond's program development model, this sequence become the basic planning input in creating the framework of an ideal course (see Figure 1) with housing course as a case study.

I Faculty member, Deparment of Architecture Faculty of Engineering Universitas Islam Indonesia (currently taking Master of Arcitecture Post Professional Program at Technical University of Nova Scotia, Halifax, Canada) 
Figure 1. Diamond's program development model

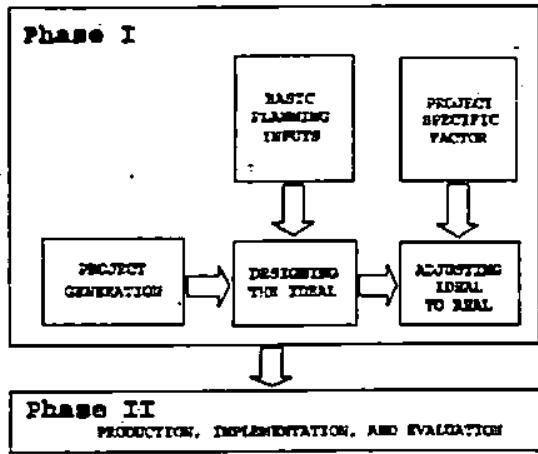

Source : Diamond 7

The Bauhaus Curriculums : A Brief Review

In his Bauhaus and Bauhaus People, Neumann speaks indirectly that an ideal architectural teaching means a method of educating students to enable them thinking independently in order to discover their own way in designing buildings (Neumann 19). In other words, students design sould reflect their own thoughts, not a replication of their teacher's thoughts. Neumann argues against Frank Lloyd Wright's methods which he consideres as a failure, since all of Wright's students took Wright's design as their precedence.

Provided that Bauhausexisted in four different places and times, the following review discusses each curriculum of the Bauhaus, form the beginning of its existence in Weimar ghrough the opening of the Bauhaus in Chicago:

\section{Bauhaus Weimar (1919 - 1925$)$}

The basic concept of Bauhaus training was to induce students' creative minds by allowing them to observe their.potential talents on design, through self-taught knowledge and personal experience in design. To develop such cognitive skill, adequate training of the hands and eycs must first be given (Gropius 55). In this sense, Bauhaus Weimar offered a six-month preliminary course on designing forms and experimenting with different materials such as wood, glass, clay, and metal. At this stage, teaching of certain stylistic forms was avoided (Gropius 71).

After finishing the preliminary courses, students would receive admission permits for joining the second stage : instruction in crafts and form problems, in which students were trained by two masters; one, an artist, and the other, a craftsman. This stage took three years to complete. Furthermore, for some time, the journeymen (students of the second stage) were required to work at a trading company's workshops, which was aimed at creating a mutual relationship; the journeymen could experience a real industrial climate, where as the company could benefit from the innovation of design as a result of the Bauhaus training.

The last stage was instruction in architecture. This stage was the culminating point of Bauhaus training, as Gopius conceptualized in the opening of this school:

The ulimate of all creative activity is the building ! The decoration of buildings was once the noblest function of the fine arts, and the fine arts were indispensable to great architecture. Today they exist in complacent isolation, and can only be rescued from it by the consious co-operation and collaboration of all craftsmen. Architects , painters, and sculptors must once again come to know and comprehend the composite character of building .... (qtd, in Naylor, The Bauhaus Reassessed 54) 
The passage shows the tremendous responsibility of an architect in designing buildings. Therefore, the last stage of Bauhaus Weimaronly admitted "gifted" journeymen, who first had to pass the special Bauhaus Journeymen test. Conceptually, the journeymen's interests. However, thisstage was never realized because Bauhaus had to move to Dessau in 1926 due to economic and political constraints (bayer 95-96)

Thus, the training at Bauhaus Weimar consisted of three stages : preliminary course, instruction in crafts and form, and instruction in architecture. The boundary of each stage was very clear, given the fact that each stage appeared as an "independent" learning environment. In other words, every student

Figure 2 Courses at Bauhaus Weimar

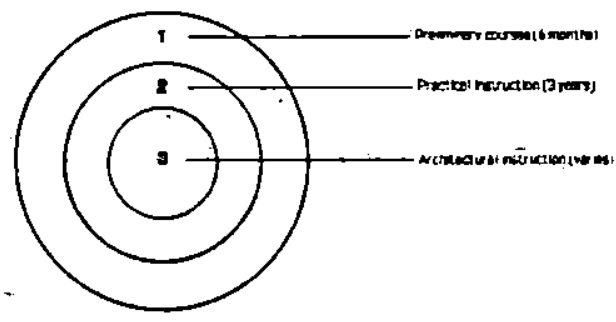

Source : adapted from Naylor, The Bauhaus Reassessed 73

should get a well-rounded knowlegde after completing each stage Using a round chart the relationships between each stage can be visualized as shown in Figure 2.

\section{Bauhaus Dessau ( 1926 - 1932)}

In 1925. Bauhaus has to move to Dessau due to budget cuts by the Weimar authority. It began to operate in 1926 with the major support from the Dessau city council, which provided funds for erecting
Bauhaus school buildings and housing for Bauhaus masters.

The sequence of instruction remained the same : however, in the seconds stage (pratical) instruction, students were not taught by dual masters anymore (Bayer 96). It was assumed that the masters already had adequate proficiency in both art and crafts, as a result of their previous experience in Weimar. The courses at this stage were developed to allow joumeymen to choose specialization of design according to their interests and talents (Wingler 122)

Figure 3 shows that architectural instruction was given in three semesters, whereas in the Weimar curriculum, the length of architectural instruction varied, depending upon the joumeyman's case study. In fact, the architectural istruction was never realized in Weimar (Dearstyne 199)

In 1927, the Departement of Architecture was opened and chaired by Hannes Meye. He developed the sequence of instruction so that the students had more opportunity to access the architecturallevel of courses. Workshops on architecture were given in the second and third semesters, and students were free to choose the kind of workshops (e.g. fumiture workshop or wall painting). However, students had to attend the preliminary courses as the prerequisite of architectural workshops even if they had already had architectural training before entering the school (Wingler 151). This stage was aimed at developing a "common design language" among bauhauslers (the bauhaus people).

The literature that documents the Bauhaus teaching dossier does not given a clear explanation whether the courses sequence at the Departement of Architecture 
(Figure 4) replaces the previous scquence (Figure 3) or not. Apart from it, the curriculum shown in Figure 4 still reflects Gropius'. idea that " the ultimate of all creative activity is the building ! " (qtd. in Naylor, The Bauhaus Reassessed 54).

Figure 3. Courses at Bauhaus Dessau

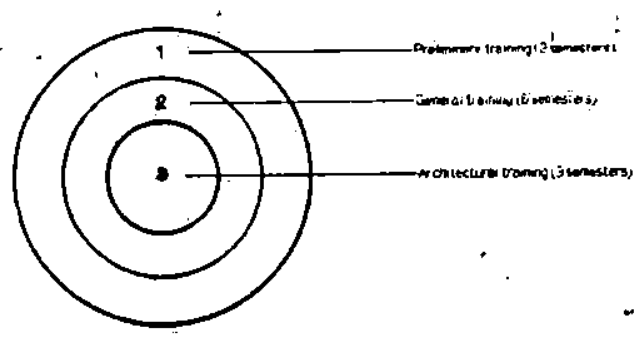

Source : adapted from Wingler 107 Figure 4. Courses at Departement of Architecture (Dessau)

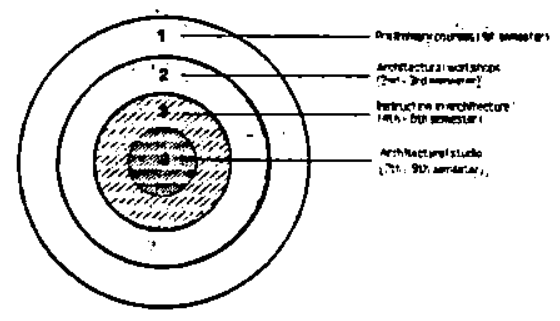

Source : adapted from Wingler 151

\section{Bauhaus Berlin ( 1932 - 1933)}

It was unfortunate that Bauhaus had to be closed again. The reason this time was more political than financial. The Nazis "forced" the Bauhaus closing through financial supply cut by the Dessau city council, because of the strong Communist movement among the students (Wingler 177). Shortly after the closing, Miss van der Rohe, the latest Bauhaus Dessau director, dicided to re open the Bauhaus as a private institution in Berlin (1932). How- ever, it ran only one year, because in 1933 it was closed again by the Nazis.

Unlike the previousBauhaus aproaches, the culminating point of training sequence at Bauhaus Berlin was not merely in architecture. At the second stage, students had to choose specialized workshops according to their interests. Furthermore, in the third (last) stage the chosen workshops were developed through independent work.

Figure 5. Courses at Bauhaus Berlin

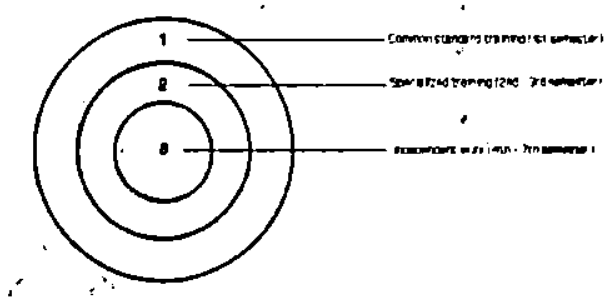

Source : adapted from Wingler

The New Bauhaus Chicago (193-1938). After the dissolution of the Bauhaus School in Berlin, most of the Bauhaus masters moved to the United States. Obviously, because of their reputation, they had been invited to teach there. Gropius was appointed to lecture at Harvard, while laszlo Moholy-Nagy was asked to establish the New Bauhaus school by the Art Institute of Chicago (Wingler 193). Yet, this school existed only for one year due to the lack of financial support and the economic depression at that time in the Unites States.

Despite the political and financial problems that challenged the Bauhaus school and forced them to be closed, the infuluence of Bauhaus and the spread of its educational concepts did not end at the Bauhaus school. In fact, Harvard University and Massachusetts Institute of Tech- 
nology became the center of Bauhaus culture in the United States (Wingler 572), As well

Figure 6. Courses at the Bauhaus, Chicago

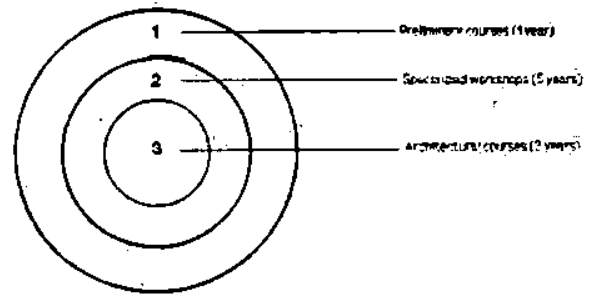

Source : adapted from Wingler

Mies van der Rohe developed his Berlin Bauhaus' concept at the Illionis Institute of Technology in Chicago, an institution still enjoy a very favorable reputation today. Figure 6 shows the sequence of instructions at the New Bauhaus Chicago which is some what similar to that of Weimar Bauhaus, except in the intermediate course.

Referring to Teaching Architecture by Omer Akin ( a teaching fellow from Camegie-Mellon University), the Bauhaus' sequence of instructions can be categorized as experimental teaching. (17). In this method the flow of teaching begins with expérience and ends with assimilation (see Figure 7). Analogically, the preliminary instruction is the assimilation, whereas the instructions between those two become the abstraction and application (see Figure 8).

Figure 7. Experiment teaching

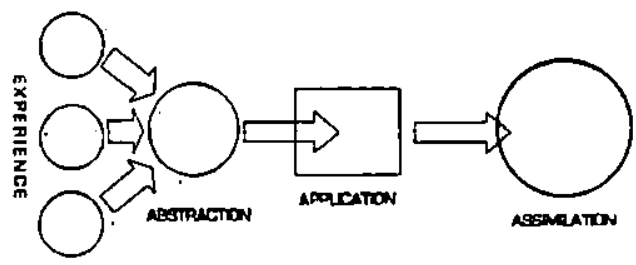

Source : adapted from Akin (17)
The above model shows that experiment teaching begins with introducting the students to experince in exercise of particular design actions, to value those actions and their consequences. Furthtermore, trought abstracting these experinces, students are ecxpeted to find the principlses that can be suitably applized for specific design purposes. The next step is to apply the knowlegde (as a result of abstraction) for certain désgin actions other than ones that have been discussed in the first step (experience). Finally, the students shall be able to assimilate all the knowlegde obtained from the previous steps.

* Thus, in the preliminary course of the Bauhaus, the students were encouraged to understand what the problems were, then in the intermediate instruction (i.e. practical instruction, general training, architectural workshops, or specialized training) they could become familiar with the problem and consequently, learn to solve these problems. Finally, in the architectural instructions (i.e. studio course) the students became competent in design, as Pena (15) arques that design is a means of solving problems.

In Knapper's survey, most faculty argue that teaching is an attempt to stimulate students' thinking and learning. In other word, those faculty believe that the objective of teaching is "to develop students' cognitive skill" (Teaching and Effectiveness in The University of Alberta 23 ). According to Schon (1987), the character of a profesional school is marked by the activity of transforming indeterminate circumstances into determinate ones (Carroll 3) to enable students to students to solve problems. Problems solving requires cognitive skill, Further, Schon (1987) proposes 
the "coaching approach" using an example of instruction in an architectural studio.

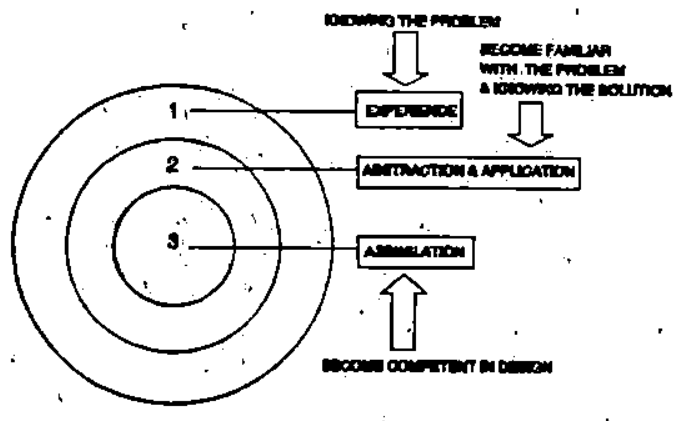

Figure 8. Proposed sequence : the application of Akin's model to the Bauhaus instructional sequence

Judging from these arguments. Bauhaus obviously appears to have been an ideal profesional school. The role of dual masters instructing journeymen in the Weimar Bauhaus was to coach the journeymen to developed their own "style" in design, based on self- taught knowledge. Neuman.(215) takes the Bauhaus method as an example of ideal teaching on architecture, which he defines as a method of enabling the students to discover their own design attitudes. He argues against the methods of an intemationally recognized American architect. Frank Lloyd Wright, whom he considers a failure, since. all of Wright's students apparently took Wright'a design as their precendance.

\section{POSSIBLE APPLICATIONS FOR TEACHING A'RCHITECTURE (CASE STUDY : HOUSING COURSES)}

To find the possibilities of applying the Bauhaus concept for teaching architecture today, the model shown in Figure 8 is used as a reference for reconstructing sequence of the existing Housing sourses. Based on Diamond's program development model (Figure 1), the proposed sequence (Figure 8) and the existing courses (Figure 11) become the planning input.

According to Diamond, outlining an ideal course can be undertaken after the operational sequence of curriculum is established (103); if necessary the curriculum shall be approved before beginning to outline the course. Figure 9 shows the transitional process of the curriculum and course projects from outlining the ideal to adjusting the ideal to the real conditions.

- To reconstruct the sequence of the existing courses, the above model is modified (see Figure 10),' with the sequence of existing courses placed in the third step. The fourth step is therefore the result of the reconstruction. The case study is taken from the surricula of the School of Architecture Universitas Islam Indonesia (see Figure 11 ) in which the housing course is divided into four: Principles of Housing Planning and

Figure 9. Transitional process of curriculum and course project:

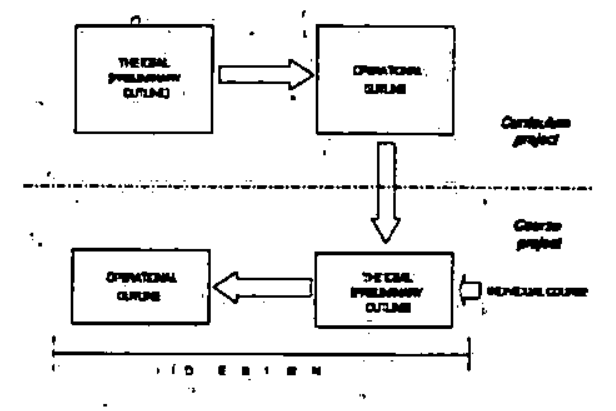

Source : Diamond 103

Disign I (PHPD I ), PHPD II: Teahniques of Housing Planning and Design I (THPD I ), and THPD II.

Currently, PHPD I fully discusses the theoretical aspects of housing. Yet, these theories cover up to $70 \%$ of the total 
course material in the PHPD II. The ramaining $30 \%$ is site observation exercises (based on 1990 teaching dossier). Students begin to see the real housing problems in the THPD I where they concentrate more extensively on housing survey. The workshops on the planning of housing development are offered in the THPD.II. In this course, students attempt to solve the housing problems through the coaching method (studio works).

Thus, in these existing course, students are introduced to a rigid or "ready made" formula at the beginning, then they are asked to apply the formula at the intermediate step. The final step is assimilation, by which the students are trained to solve the housing problems. This sequence is categorized the didactic teaching (Akin 17), which is visualized in Figure 12.

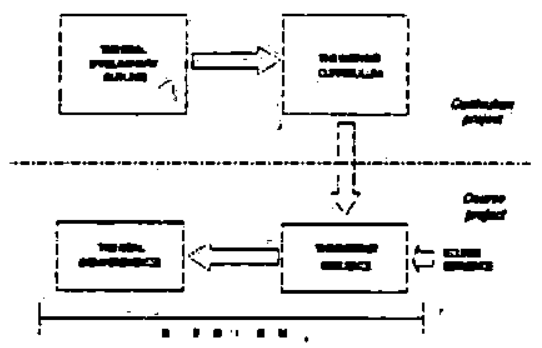

Figure 10. Modification of model in Figure 9

The sequence of didactic teaching is an obvious contranst to the Bauhaus educational concept, which relies heavily upon the discovery of students' skill in mastering design. Therefore, to fit with the Bauhaus concept, the existing sequence is reconstructed as shown in Figure 13.

The modified sequence (Figure 13) shows the changing of sequence structure. In the fourth semester, students are introduced with the problem of housing through survey or observation activities. In this case, the students are asked to produce reports of theirobservations and/or surveys which include their opinion toward the problems. This new course is entitled $I n$ troduction to Planning and Design Techniques of Housing ( I PDTH ).

Figure 11. The existing sequence of Housing courses at the School of Architecture. Universitas Islam Indonesia

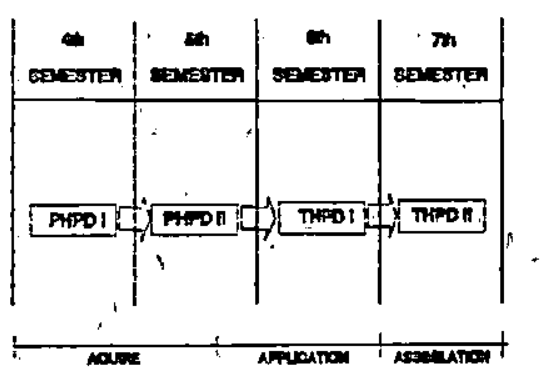

Figure 12. The sequence of didactic teaching

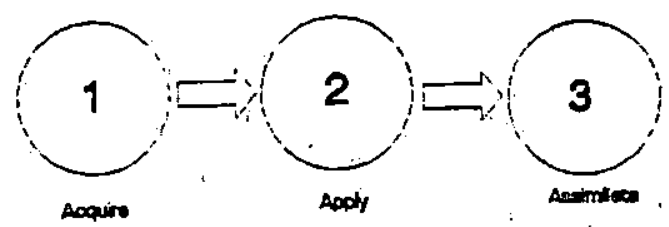

Source : adapted from Akin 17

PHPD I is moved to the fith semester and consequently PHPD II is moved to the sixth. In this new sequence. PHPD I serves as a theoretical source which gives opportunity to the students to relect the problems of housing based on their experince from the previous course. Furthermore, in the PHPD II the students apply the theory and their experience to elaborate the desgin concept. Finally, in the THPD which is offered in the eighth semester, they concentrate more extensively on planning and ucsigning housing for the urban and regional context. 


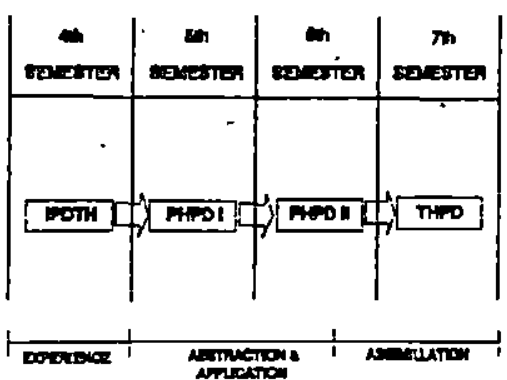

Figure 13. The modified sequence Note : IPDTH = Introduction to Planning and Design Techniques of Housing.

\section{SUMMARY}

The Bauhaus educational concept obviously appears as an ideal model for the professional shools. However, without considering the real conditions, direct application of this concept may.constrained by numbers of hardware problems which will likely lead to the impossibility. This paper attempts to develop a typical sequence of teaching based on the evaluation of the Bauhaus curriculum and Akin's experimental teaching concept. A case study is used to apply the sequence, channelled by the Diamond's program development model.

\section{BIBLIOGRAPHY}

Akin. Omer, "Teaching Architecture" Proceedings of The 69th Annual Meeting of The Association of Collegiate School of Architecture 1981 : $16-30$.

Bayer, Herbert, and Walter Gropius, Bauhaus 1919-1928, Boston Charles T, Branford Company, 1959.

Carroll, Ray F, " A book Report on Donald A. Aschon (1987) Educating The Reflective Practitioner. " Assigment for Education 5530 A. Faculty of Education, Dalhousie University, Fall 1991.

Dearstyne, Howard, Inside The Bauhaus, New York : Rizzoli, 1986.

Diamond, Robert M. Designing and Improving Courses and Curriculg in Higher Education, San Francisco : Jossey-Bass Inc... 1989.

Gropius, Walter, New Architecture and The Bauhaus, Cambridge : The MIT Press, 1965.

Knapper, Christopher, "Teaching Effectiveness at The University of Alberta : Practices, Attitudes, Plan, "Report of IPTE : The Inventory Plan for Teaching Effectiveness November 1988.

Naylor, Gillian. The Bauhaus Reassesse : Sources and Design Theory, New York : E. P. Dutton, 1985.

Neumann, Eckhard, Bauhaus and Bauhaus People, New York : Van Nostrand Reinhold Cmpany, 1970.

Pena, William, and William Caudill, Problem Seeking, An Architectural Progamming Primer, Boston, Mass : CBI Publishing Company Inc... 1977.

Universitas Islam Indonesia, BukuPedoman Fakultas Teknik Jurusan Arsitektur 1990/1991, Yogyakarta : Fakultas Teknik Universitas Islam Indonesia, $1990^{2}$

Wingler, Hans M. The Bauhaus : Weimar, Dessau, Berlin, Chicago, Cambridge : The Massachusetts Institute of Technology, 1969.

${ }^{2}$ The Teaching Guiselines for Departement of Architecture, Faculty of Engineering. Universitas Islam Indonesia 